\title{
Role of Clay Minerals in the improvement of Water Quality in the Kingdom of Saudi Arabia (KSA)
}

\author{
Abdullah Mohammed Alsaluli ${ }^{1}$, Adil A. M. Elhassan ${ }^{2}$ \\ ${ }^{1,2}$ Department of Civil Engineering, \\ College of Engineering Taif University, \\ Kingdom of Sudi Arabia
}

\begin{abstract}
Montmorillonite and kaolinite minerals are the territories of center in this paper just as utilization of these minerals in the Kingdom of Saudi Arabia (KSA). Various components of water quality, for example, the compound organization, natural, radiological, and physical parameters of water are the primary territories important to improve. The paper gives a concise writing survey of the minerals to set up the capability of these materials in the ideal zones of use. The report likewise surveys the engineering properties of kaolinite and montmorillonite minerals circulation in the Kingdom of Saudi Arabia (KSA) district to discover the likelihood of utilizing these materials for water treatment. The region is altogether secured by a desert; henceforth, water treatment is a noteworthy worry in this district. A basic investigate the science of how these materials work is done in the talk area of this paper. The uncontrolled dumping of industrial waste is causing serious problems to water resources in many areas, jeopardizing the balance of different ecosystems and the health of their inhabitants. The problem of water pollution has made the control of waste more demanding and that more and more restrictive standards are established on the permitted content of toxic compounds in industrial discharges.
\end{abstract}

Keywords-Montmorillonite, kaolinite, minerals, Clay, Water.

\section{INTRODUCTION}

The storage of molecules on a surface is called adsorption. It is a process that occurs at the surface level and consists of the accumulation of different chemical species (molecules, ions or atoms) on the surface of a material. Unlike absorption, where what is absorbed is chemically transformed, in adsorption, the chemical identity is preserved. Bentonites, due to their laminar structure, small particle size and negative surface charge, have great potential as an adsorbent.

Clay is a natural component of the soil, formed over centuries by the effect of meteorological phenomena on a particular type of rock, feldspathic. It is part of a large group of minerals called phyllosilicates (phyllon = leaf) that are characterized by having a structure of leaves or scales of a negative charge, joined by cations (particles of positive charge) which have the ability to hydrate, that is, Surround yourself with water molecules. This ability gives clays the characteristic plasticity that makes them moldable. The subsequent removal of water molecules during drying at temperatures greater than $800{ }^{\circ} \mathrm{C}$, causes hardening, firmness, and impermeability. In addition to its use in the elaboration of objects and ornaments, Millennially, a type of clay called bentonite was used to extract fats, oils and other substances from sheep's wool for the manufacture of tissues. Today such materials are used to remove grease, oils or other undesirable organic substances in the floors of factories, hangars, garages, warehouses, etc.

One type of compounds that this research group seeks to adsorb in bentonites are fungicides, substances that attack fungi and molds and that are used, for example, in the treatment of fruits so that they can be stored for long periods and reach the market in good condition. However, these fungicides are potentially toxic to aquatic life, and large volumes of water containing them are generated in the fruit packaging plants where they are used and then discarded into natural watercourses.

In order to remove fungicides from water, the adsorbent capacity of natural clay and chemically modified clays is being evaluated by intercalating organic compounds between their sheets (organo-clays).

The adsorption experiment consists of making a mixture of clay with the contaminated water, keeping it under stirring for a few hours and finally separating the "cleaner" water from the mud (clay with adsorbed fungicide) that falls into the bottom of the container. After several years of work, hopeful results (high removal capacity) have been found for some families of fungicides, while the adsorption study of other families is continued to improve the efficiency in the treatment of wastewater from the fruit industry.

Traditionally, clays have been considered as ceramic raw material, scarcely realizing their geological and economic importance in a variety of industries that have resulted in a wide and complex technology, dispersed and often ambiguous. In our environment, its study has been promoted on a small scale both in its scientific and geological and technological aspects, so that, at present, local materials are used in the ceramic industry but, even it and many others, depend to a large extent on imported material. Moreover, geological, mineralogical or technological knowledge is scarce, often occurring the fact that clay is used because it 'works' in its final use without knowing much about its characteristics. Hence, it is considered convenient to disseminate some elementary concepts that can help both the geologist and the minerlogue as well as the technician.

Commercial clays, which serve as industrial raw material, are among the most important mineral resources, both for the 
volume exploited and for the value of production. $90 \%$ of the production is preferably dedicated to the manufacture of construction materials and aggregates, and only $10 \%$ is dedicated to other industries. Those used in construction are called ceramic clays and are composed of two or more clay minerals, usually ilite and smectite, with significant amounts of other minerals that are not phyllosilicates. The second type is called special clays, They are predominantly made up of only one type of clay, and their properties depend essentially on the characteristics of that mineral. Special clays can be divided into kaolin and kaoliniferous clays (with very low adsorption power), bentonites, sepiolite, and paligorskite.

Kaolinite has 1 layer of Sio4 tetrahedra sheet, and montmorillonite has two sheets of tetrahedra. Clay and organic matter $(\mathrm{OM})$ are pillars of the soil structure; the clays that flocculate form stable domains and together with the $\mathrm{OM}$ act as binding material between the mineral particles in the formation of the structure. OM can be accommodated in small pores, which generate bonds between particles and influence soil resistance, especially in larger aggregates, however, argue that organic compounds can be adsorbed on clays that modify the RC of soil aggregates.

Macks et al. [5], maintain that the resistance of the soil and its friability are influenced by the type and quantity of the clay fraction, the interchangeable cations and the proportion of dispersible clay in the soil. Dexter et al. [2] found that the dispersibility of clay increases with the amount of clay not complexed by $\mathrm{CO}$; they concluded that approximately $10 \mathrm{~g}$ of clay are complexed with $1 \mathrm{~g}$ of $\mathrm{CO}$. It has been shown that large amounts of dispersible clay can increase the CR and reduce the IF in dry aggregates [4].

Relatively stable organo-mineral associations can provide greater resistance to the physical breakdown of soil aggregates with tillage, especially in soils with fine textures ( Jindaluang et al.[3]). Likewise, Bruun et al. [1] mention that the stabilization capacity of the MO is not the same for all types of clay and suggest that the capacity is greater in 2: 1 clay than in 1: 1 and decreases to follow the allophane sequence> smectite $>$ illita $>$ kaolinite.

\section{RESEARCH PROBLEM}

From the literature review, valuable research on clay mineral has been conducted. However, studies are still needed for providing comprehensive information, including the effects of clay minerals on permeability, soil suction, compaction energy, resilient modulus, and microstructure gave the wide range of mineralogical composition of clay soils of KSA. Research is needed to contribute to knowledge in areas such as the effect of clay mineralogy on the on Water Quality in the Kingdom of Saudi Arabia (KSA). In addition, the effects of clay mineralogy on the engineering properties of clay soils need assessment.

\section{MATERIALS}

Two tropical clay soil samples were selected, taking into consideration variation in mineral composition of the clay (kaolinite and Montmorillonite). These soil samples were obtained from the depth (between 0.5 to $3.0 \mathrm{~m}$ ). The description of the mineralogical characteristics of each soil samples presented in Table 1.

Table 1. XRD test results of the soil samples

\begin{tabular}{|c|c|c|c|c|c|}
\hline \multirow{2}{*}{ Sample } & \multicolumn{5}{|c|}{ Mineralogical Composition } \\
\cline { 2 - 6 } & $\begin{array}{l}\text { Smectite } \\
\%\end{array}$ & $\begin{array}{l}\text { Kaolinite } \\
\%\end{array}$ & $\begin{array}{l}\text { Illite } \\
\%\end{array}$ & $\begin{array}{l}\text { Chlorite } \\
\%\end{array}$ & $\begin{array}{l}\text { Sme/Illi } \\
\%\end{array}$ \\
\hline Soil 1 & 90 & 10 & 00 & 00 & 00 \\
\hline Soil 2 & 00 & 89 & 00 & 11 & 00 \\
\hline
\end{tabular}

\section{MINERALOGICAL EXAMINATION OF THE SOIL SAMPLES}

The mineralogical characteristic of the soil samples was examined by X-ray diffraction (XRD). The test was carried out using advanced X-ray diffraction apparatus. Computer programs which are Philips $\mathrm{X}^{\prime}$ Pert Organiser were used for quantification of the mineralogy composition of the soil samples. Table 1 and Figure 1 through Figure 2, shows that Soil 1 sample is predominantly montmorillonitic (90\%) with $10 \%$ kaolinite and Soil 2 sample is basically kaolinitic.

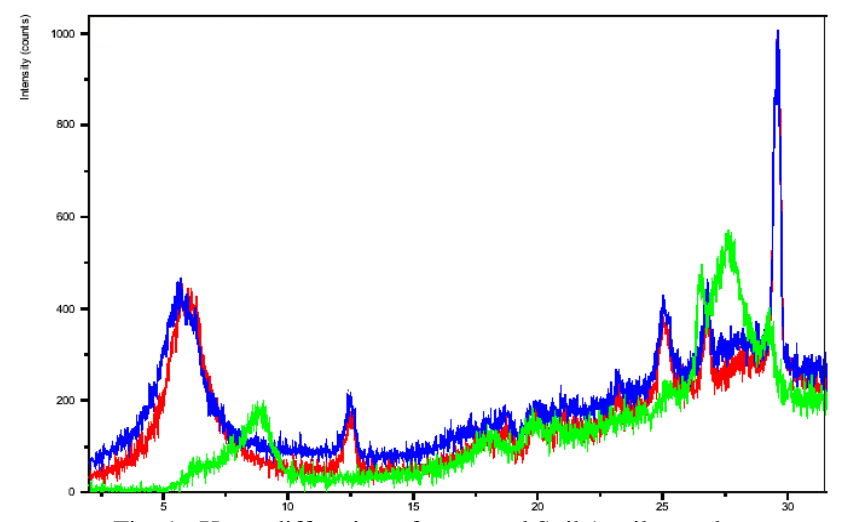

Fig. 1. X-ray diffraction of untreated Soil 1 soil sample

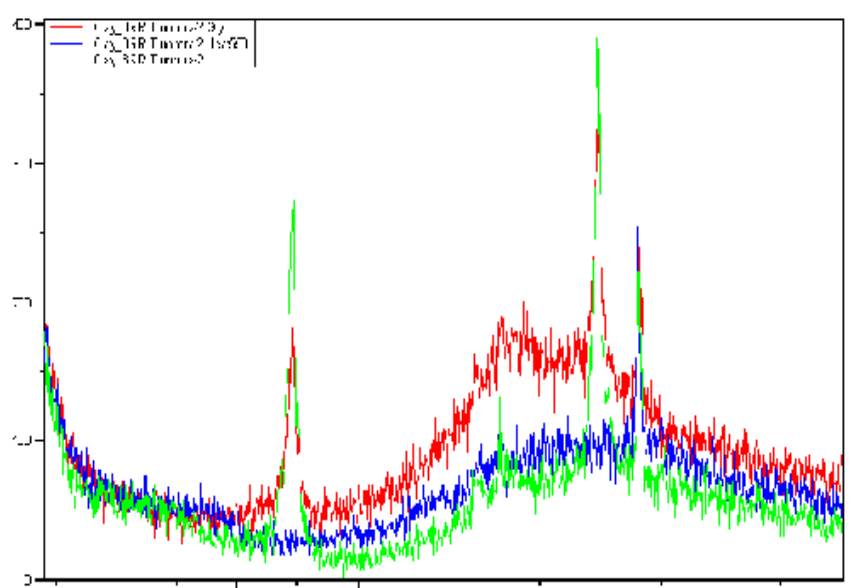

Fig. 2. X-ray diffraction of untreated Soil $\ddot{2}$ soil sample

\section{CHEMICAL EXAMINATION OF THE SOIL SAMPLES}

A chemical test for the two soil samples was carried out. These tests were carried for the soil samples to know their different chemical of the pore water such as; $\mathrm{Na}+\mathrm{Ca}+\mathrm{Mg}+$, Ece, SAR, SAT, TP, CEC, and ESP. The test sample was mixed with distilled water until the consistency is approximately that of the liquid limit, or known as "saturated 
soil paste," then allowed to stay for two hours until equilibrium took place between the salts in the pore water and on the cation exchange complex. Subsequently, a small quantity of the pore water was extracted from the saturated soil paste $(10-25 \mathrm{ml})$ using a vacuum of filters. The extracted water is called "saturation extract." This saturation extract is then tested by testing procedures employed by the chemist to determine the amounts of the main metallic cations in solution (calcium, magnesium, sodium).

The results of this test are commonly given in terms of the Sodium Absorption Ratio (SAR) calculated by the Equation 1:

$$
\mathrm{SAR}=\mathrm{Na}+/(0.5 \mathrm{x}(\mathrm{Ca}+2+\mathrm{Mg}+2))^{\wedge} 0.5
$$

Where $\mathrm{Na}+\mathrm{Ca}+2$, and $\mathrm{Mg}+2$ have dissolved salts in milliequivalents per liter of saturation extract. In addition, the total Cation Exchange Capacity (CEC) of the clay is measured in terms of milliequivalents per hundred grams of dry soil. Also measured is the relative amount of the basic cations frequently given in the form of the "Exchangeable Sodium Percent"(ESP) which is computed by Equation 2:

$$
\mathrm{ESP}=100 \times \mathrm{Na}+/ \mathrm{CEC} \%
$$

Where $\mathrm{Na}+$ is the amount of sodium on the exchange complex in terms of milliequivalents per 100 grams of dry soil. Both ESP and SAR are measures of the relative amount of sodium in the soil. Other measurements were reported, such as Past Saturation Percent and Electrical Conductivity of the saturation extract (Ece). The latter was measured using a conductivity meter. All the results of chemical testing are reported in Table 2.

Table 2. Chemical test results for the soil samples

\begin{tabular}{|l|c|c|}
\hline Chemical test results & Soil 1 & Soil 2 \\
\hline Ece & 0.50 & 0.20 \\
\hline $\mathrm{Na}+$ & 3.10 & 0.90 \\
\hline $\mathrm{Ca}+$ & 1.5 & 1.0 \\
\hline $\mathrm{Mg}+$ & 0.5 & 0.5 \\
\hline $\mathrm{SAR}$ & 3 & 1 \\
\hline $\mathrm{SAT} \%$ & 67 & 42 \\
\hline $\mathrm{CEC}$ & 83 & 13 \\
\hline ESP & 4 & 2 \\
\hline TP & 0.94 & 0.26 \\
\hline
\end{tabular}

Where:

Ece: Electrical Conductivity. CEC: Cation exchange capacity. Percent.

SAR: Sodium Absorption Ratio.

SAT: Saturation soil paste

TP: Total Potassium

\section{TESTS FOR ENGINEERING PROPERTIES}

Based on the clay mineralogy of the soils, Soil 1 soil sample known as swelling soil, whereas the Soil 2 soil sample is red lateritic soil. Basic tests (Gs, CC, and Atterberg limits) were carried out on the soil samples, and the results are given in Table 3. Based on the Unified Soil Classification System
(USCS), an Soil 1 soil sample was classified as inorganic clay of high plasticity $(\mathrm{CH})$, and Soil 2 soil sample was classified as inorganic clay of low plasticity (CL).

Table 3. Particle size analysis of the soil samples

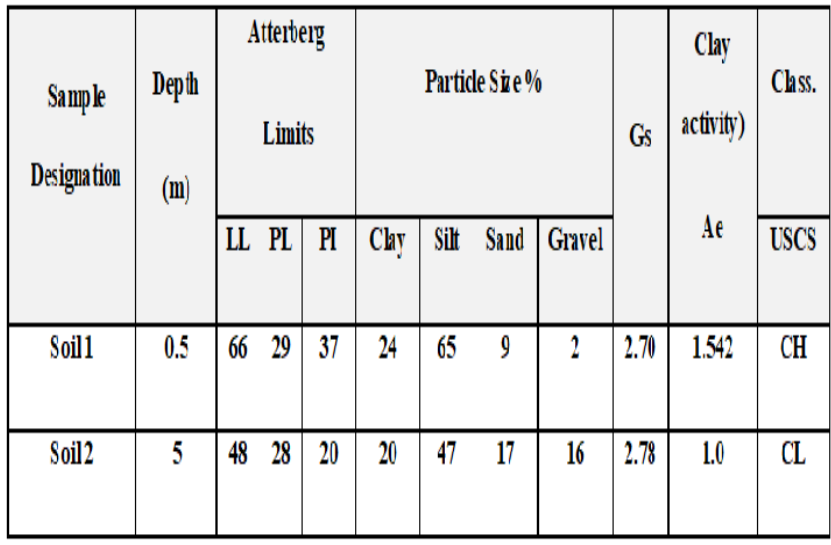

\section{PARTICLE SIZE DISTRIBUTIONS}

Particle size distribution was carried out for the soil samples for quantitative determination for the particle size greater than $0.075 \mathrm{~mm}$, and by hydrometer analysis method, for particle size smaller than $0.075 \mathrm{~mm}$ (clay and silt). The results are summarized in Table 3 .

\section{SPECIFIC GRAVITY (GS)}

The test was carried out on the soil samples. The specific gravity is the ratio of weight in air of a given volume of soil solids to the weight of an equal volume of distilled water, at a given temperature. A $50 \mathrm{ml}$ density bottle was used. The bottle was weighed empty. A quantity of dry soil (12 gram) was placed in the bottle, and the bottle weighed. The bottle was filled with water, air removed by stirring, and weighed again after 24 hours. The bottle was emptied, cleaned, and refilled with water and weighed again. The results of specific gravity for the soil samples are summarized in Table 3.

\section{ATTERBERG LIMITS}

The effect of clay mineral on Atterberge Limits was first studied. The soil samples were sieved through No. 40 Sieve. The liquid and plastic limit tests were carried out using the falling cone method and B.S. 1377-1990 test procedures [6]. The test results are given in Tables 3 .

\section{LINEAR SHRINKAGE}

The linear shrinkage test consists of placing a paste of soil passing the No. 40 sieve at its liquid limit moisture content in the of linear shrinkage mold, dry it first in the air for 24 hours and then complete the drying in the oven at a temperature of $105^{\circ} \mathrm{C}$ to $110^{\circ} \mathrm{C}$ to get a completely dry sample. After it had dried, the final length of the soil is measured. The sample inside the mold loses moisture due to drying from the top surface, which has the maximum shrinkage. The shrinkage amount decreases with the depth inside the mold so that the top surface will lie under tension stresses due to shrinkage also the tension will decrease with depth. The results are shown in Table 4. 
Table 4. Linear shrinkage of the soil samples

\begin{tabular}{|c|c|}
\hline Sample Designation & LS \\
\hline Soil 1 & 19 \\
\hline Soil 2 & 16.0 \\
\hline
\end{tabular}

\section{FREE SWELL}

The test of free swell is performed by passing the dry soil of a known volume through No.40 sieve into a graduated cylinder filled with water and calculating the increased volume due to swelling once the material is totally solid. The free swell of the soil was the ratio of the change in volume to the initial volume expressed as a percentage. The results are shown in Table 5.

Table 5. Free swell for soil samples

\begin{tabular}{|c|c|}
\hline Sample Designation & FS \\
\hline Soil 1 & 167 \\
\hline Soil 2 & 90 \\
\hline
\end{tabular}

\section{COMPACTION TEST}

The moisture-density relationship of the soil samples was calculated by performing the Ordinary Proctor compaction tests. The No.4. sieve was used for t soil samples for sieving. The British standards (BS 1377-1990) [6] were followed for carrying out all the test procedures. The compaction parameters for each test are summarized in Table 6 .

Table 6. Compaction test results for soil samples

\begin{tabular}{|c|c|c|}
\hline \multirow{2}{*}{ Sample Designation } & \multicolumn{2}{|c|}{ Compaction } \\
\cline { 2 - 3 } & $\begin{array}{c}\text { O.M.C } \\
\%\end{array}$ & $\begin{array}{c}\mathrm{MDD} \\
\mathrm{g} / \mathrm{cm}^{3}\end{array}$ \\
\hline Soil 1 & 24.3 & 1.43 \\
\hline Soil 2 & 21.0 & 1.64 \\
\hline
\end{tabular}

\section{PERMEABILITY TEST}

The effect of clay mineral on the hydraulic conductivity of the soil samples was measured by Triaxial cell apparatus shown in Figure 7 by applying flexible membrane permeability test method (BS 1377: 1990, Part 6). The standard Proctor mold was used to compact the samples at optimum water content using Standard Proctor energy. The samples were mounted in the triaxial cells after the preparation. The saturation of samples was done to over $95 \mathrm{~B}$ value using back pressure saturation. The test was conducted according to the mentioned standard. The test results of the permeability test for Soil 1 and Soil 2 soil samples are shown in Table 7.

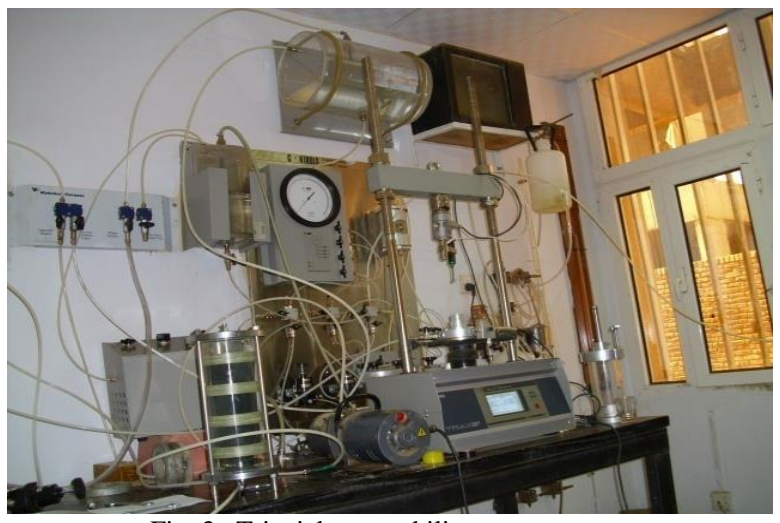

Fig. 3. Triaxial permeability test apparatus
Table 7. Permeability values for the soil samples $(\mathrm{m} / \mathrm{sec})$

\begin{tabular}{|c|c|}
\hline Sample Designation & K-value $(\mathrm{m} / \mathrm{Sec})$ \\
\hline Soil 1 & $1.5 \mathrm{E}-10$ \\
\hline Soil 2 & $1.0 \mathrm{E}-8$ \\
\hline
\end{tabular}

\section{ANALYSIS AND DISCUSSION OF RESULTS}

\section{A. The Effects of clay mineral on Atterberg Limits}

The Atterberge limits tests attempted to study the effect of kaolinitic and montmorillonite on plasticity and workability. The results shown in Tables 3, showed that the kaolinitic soil sample decreased their liquid limit, increased their plastic limit, and consequently reduced their plasticity index.

\section{B. Effect of kaolinitic and montmorillonitic on Linear} Shrinkage (LS)

The objective of this test was to study the effects of kaolinitic and montmorillonitic on the shrinkage properties of the soil samples. Results indicated that the linear shrinkage decreased with increase in kaolinitic content.

\section{Effect of kaolinitic and montmorillonitic on Free Swell}

From the results shown in Tables 5 for the soil samples, it is clear that kaolinitic soil samples decreased their free swell. kaolinitic soil samples showed significant effects on decreasing free swell compared to the montmorillonitic soil sample.

\section{Effect of kaolinitic and montmorillonitic on Dry Density} and Optimum Moisture Content

The results of the compaction tests are summarized in Table 6. The results show that the kaolinitic soil sample increased their maximum dry density and reduced their optimum moisture content for the same compaction effort. The increase in their maximum dry density and the drop in optimum moisture content look almost the same for the two increment steps.

E. Effect of kaolinitic and montmorillonitic on Permeability

The triaxial permeability test results are given in Table 7 . The results showed that kaolinitic and montmorillonitic clay soils resulted in a very high increase (1000 times) in K values for the soil samples. The porosity of the soil was indirectly measured by the increase in permeability as an evidence. The aggregated of several sizes were formed by the reaction of clay minerals (kaolinitic and montmorillonitic)

\section{CONCLUSION}

This research presented the outcome of a program of intensive laboratory tests aimed at studying the effects of clay mineral on the engineering properties two clay soil samples. The mineralogical characteristics of the clay fraction were varying. Soil 1 is predominantly montmorillonitic; while Soil 2 soil sample is mainly kaolinitic. From the results of this study, the following conclusions have been drawn:

i. A significant linear relationship is found for the drop in the plasticity index for the kaolinitic soil sample compared to montmorillonitic soil sample.

ii. The kaolinitic soil sample decreased their linear 
shrinkage and free swell and therefore decreases their shrink-swell potential to the limits that satisfy the requirements for road subgrade and pavement materials.

iii. The kaolinitic soil sample increased their maximum dry density and reduced their optimum moisture content.

iv. Permeability increased substantially (> 1000 times) on the kaolinitic soil sample. The increase in permeability of the kaolinitic soil sample when they serve as sub-grades could enhance penetration of water to the lower montmorillonitic soil sample and therefore cause heaving of the pavement.

\section{ACKNOWLEDGMENT}

First of all we would like to express our great thanks to God Almighty for helping use to finish this humbly research, and this is our pleasure to express our special thanks to Scientific Research Deanship at Taif University for their full support to the scientific research at the university.

\section{REFERENCES}

[1] Bruun, T; Elberling, B; Christensen, B. 2010. Lability of soil organic carbon in tropical soils with different clay minerals. Soil Biology and Biochemistry (42): 888-895.

[2] Dexter, A; Richard, G; Arrouays, D; Czyz, E; Jolivet, C; Duval, O. 2008. Complexed organic matter controls soil physical properties. Geoderma (144): 620-627.

[3] Jindaluang, W; Kheoruenromne, I; Suddhiprakarn, A; Singh, B. 2013. Influence of soil texture and mineralogy on organic matter content and composition in physically separated fractions soils of Thailand. Geoderma (195): 207-219.

[4] Kay, B; Dexter, A. 1992. The influence of dispersible clay and wetting/drying cycles on the tensile strength of red-brown earth. Australian Journal of Soil Research (30): 297-310.

[5] Macks, S; Murphy, B; Cresswell, H; Koen, T. 1996. Soil friability in relation to management history and suitability for direct drilling. Australian Journal of Soil Research (34): 343-360.

[6] BS 1377",British Standard Institution,"Soils for Civil Engineering Purposes. London. 1990. 